\title{
The Legal and Legitimate Combat Against COVID-19: German Curfew-related Case Law
}

\section{Sebastian von Münchow}

George C. Marshall European Center for Security Studies, https://www.marshallcenter.org

\begin{abstract}
Much has been written about Chinese and Russian attempts to abuse the pandemic to reshape international order in favor of authoritarian regimes. Diplomatic initiatives, staged relief operations, and troll propaganda were rolled out when COVID-19 hit Europe and the USA in early March 2020. These activities meant to insinuate that centralized, illiberal governance models are better prepared to manage the crisis. In contrast, the transatlantic world fights the virus with measures taken in accordance with Rule of Law standards. In a previous paper, the author argued that access to legal remedies makes the difference. In spring and early summer of 2020, courts in Germany decided on a number of cases where claimants challenge lockdown regulations. Some of these decisions deserve a closer look because they deepen the understanding of how constitutional requirements are assessed in lieu of the constraints. The article, therefore, starts with a short summary of the German judicial system to challenge executive decisions. It will then turn to discuss some outstanding court rulings. In the end, the contribution attempts to assess what kind of COVID19-related case law in Germany emerges. Could the courts balance core constitutional principles, the need to keep a functioning health sector, to allow a number of basic rights untouched, and to prepare a careful economic recovery?
\end{abstract}

Keywords: COVID-19, governance, lockdown, civil rights, rule of law 


\section{Introduction}

In the wake of COVID-19, much has been written about Chinese and Russian attempts to use the crisis to reshape international order in favor of authoritarian regimes. Diplomatic initiatives, staged relief operations, and troll propaganda was rolled out when the coronavirus hit Europe and the USA in early March 2020. The intention was, and still is, to target western societies in distress. These activities insinuate that centralized, illiberal governance models are better prepared to manage the crisis. This approach neglects the question of the virus's origin, the disputable transparency to share critical information with the rest of the world, and missed opportunities to contain the spread of COVID-19 in the early phase. It also overlooks that liberal democracies must adhere to Rule of Law when applying tools to prevent further infections. In a Security Insights paper published on the website of the George C. Marshall Center in April 2020, I claimed that the only legitimate measures against the virus are those taken in accordance with Rule of Law standards. ${ }^{1}$

\section{The Virus and the Constitutionality of a Lockdown}

The Security Insights paper discussed how one of the 16 German federal states, Bavaria, introduced curfew regulations and what constitutional thresholds had to be taken into account when basic rights were going to be restricted. The case of Bavaria was chosen because it is the Land that dealt with the highest number of infected and deceased personnel and thus introduced the harshest constraints compared to states like Hamburg, Saxony, Berlin, or Rhineland-Palatine. I explained that, in Germany, the executive protection of public health falls under the jurisdiction of the Länder, the 16 German states; thus, 16 health ministries, 16 parliaments, and 16 law enforcement bodies are occupied with COVID-19. This distinction matters with regard to the internal German discussions on how to avoid or promote a patchwork of tailored-made restrictions across Germany. ${ }^{2}$ The Federal Government, however, serves as the coordinating forum.

On the question of constitutional legality, I argued that the government of the Free State of Bavaria made decisions that impacted on the basic human and civil rights of its residents. I also argued that the curfew regulations carefully balanced Germany and Bavaria's trilemma: to keep a functioning health sector, to allow a number of basic rights to remain untouched, and to prepare for a measured economic recovery. I claimed that the Bavarian government crafted regulations that satisfied basic requirements. The curfew-related ordinance precisely

1 Sebastian von Münchow, "COVID-19: How to Implement a Lockdown in a Democratic Context," Strategic Insights 57 (Garmisch-Partenkirchen, Germany: George C. Marshall European Center for Security Studies, 2020), https://www.marshallcenter.org/ sites/default/files/files/2020-06/Security\%20Insights\%2057.pdf.

2 See also: Constanze Stelzenmüller and Sam Denney, "COVID-19 Is a Severe Test for Germany 's Postwar Constitution," Lawfare, April 16, 2020, www.lawfareblog.com/ covid-19-severe-test-germanys-postwar-constitution. 
referred to Bavarian and federal laws to maintain public health. For the sake of clarity, I pointed out that Munich thoroughly formulated the practices to be prohibited and outlined which conditions allowed for exemptions. The administration stressed the temporary state of these constraints. It bought itself time to fine-tune the restrictions and to equip the health institutions.

Access to the judicial system remained open so that citizens and legal entities could challenge, in court, the provisions and implementing acts. This access to the legal system, I argued, as a basic pillar of Rule of Law, revealed that democracy kept functioning during the pandemic. ${ }^{3}$ When I wrote my first contribution to this topic, I already hinted that the judiciary could face a wave of suits by individuals and companies that would challenge curfew restrictions. I cited four early cases where individuals had already turned to the administrative courts to ask if constraints had been taken in accordance with the federal or state constitution.

In the meantime, courts have decided on a number of additional cases. It is expected that more cases will have their day in court. However, some of the recent decisions deserve a closer look in order to deepen the understanding of how constitutional requirements are assessed in lieu of the constraints. Therefore, I begin with a summary of the German judicial system that allows challenges to executive decisions. This is necessary to be able to understand the variety of differing judgments that resulted. I will then turn to discuss some outstanding court rulings. In the end, I will attempt to assess what kind of COVID-19-related case law in Germany emerges and what this means for the legitimate fight against the pandemic.

\section{The Administrative Court System in the Federal Republic of Germany}

The German system to challenge administrative acts is, in many ways, unique in comparison not only with immediate European neighbors but also on a global scale. It guarantees an all-encompassing set of options for individuals in need of legal redress. Most cases start with an administrative decision by an authority (i.e., federal, Land, or municipal) which is considered to be illegal by an affected resident (i.e., revocation of a driver's license, denial of asylum, rejection of a construction project, admittance to public universities, taxation issues, and others). The claimant is usually informed of his or her right to object to the decision. If the institution adheres to its original executive act, then the claimant is entitled to seek a legal review by an administrative court.

The first level is the local Verwaltungsgericht (Administrative Court). In this very early stage, the administrative dispute is considered purely on a state-level. An exception would be when a claimant is challenging the decision made by a

3 See also Josef Joffe, "On Coronavirus, Beware the Totalitarian Temptation," The American Interest, March 17, 2020, https://www.the-american-interest.com/2020/03/17/ on-coronavirus-beware-the-totalitarian-temptation. 
German federal authority (i.e., disputes between federal Ministries and their federal public servants on promotions or violations of duties). If the first court agrees with the initial executive act, then the affected citizen may appeal. The dispute moves up another level to the Oberverwaltungsgericht or, depending on the traditional term used at the state level, the Verwaltungsgerichtshof (Higher Administrative Court). If the claimant is faced with another negative ruling, he or she may seek a revision. This means the claimant leaves the respective Landlevel and submits the case to the so-called Revisionsinstanz at the highest administrative court level of the Federal Republic, the Bundesverwaltungsgericht. The case would formally end here. However, citizens also have the right to state that the last decision constitutes a violation of his/her basic rights. The Karlsruhebased Bundesverfassungsgericht (Constitutional Court) would then, finally, deal with the matter, but purely with a view to a violation of basic rights, as enshrined in Germany's Basic Law, the Grundgesetz. This court authority is unlike the US Supreme Court, which has the ability to re-define the law in real terms.

With regard to coronavirus-related restrictions, challenges to curfew constraints can be found in two basic procedures. First, a case could be initiated solely by the act of issuing a fine based on the COVID-19-associated violations (i.e., a caterer who disregarded the ban to host guests). The fine is the means by which the administrative act affects the claimant. He or she may then appeal to the issuing authority at the local level. If the issuing agency sees no legal or factual circumstances to change its stance, then the case would proceed to the first court level. From then on, the case would be pursued through the above-described procedures until the citizen prevails or resigns from further processes. Second, a potential appellant could also contest the various ordinances mandating a temporary curfew, which were decreed by all 16 German Länder.

The process of legally challenging a ministerial decree must pass higher thresholds than one protesting against an individually-tailored administrative act. The reason for this is that these decrees are of a collective nature. They address a certain group or all residents of a Land. They are mostly abstract in character. Most German states provide the option to challenge ordinances, ${ }^{4}$ however, the claimant has to prove that he or she is individually affected by the decree. The German legislation did not intend to allow unlimited freedom to file so-called Popularklagen (popular action). Nevertheless, the curfew constraints, introduced by the state health ministries in mid-March, were formulated in a direct manner targeting professional groups, institutions of public life, and citizens' interactions with each other. Depending on the structure of the state's administrative judiciary, a review of a respective part of the decree would need to be launched at the state-level higher courts, hence bypassing the municipal

4 See Article 120 of the Bavarian Constitution: "Every resident [...] who feels that his constitutional rights have been violated by an Administrative Body is entitled to call upon the protection of the Bavarian Constitutional Court," www.bayern.landtag.de/ fileadmin/scripts/get_file/Bavarian_Const_2003_BF.pdf. 
stage. The court would then declare the disputed part as a legal violation, not the decree per se.

In consequence, the legislating authority would need to rewrite the section at stake in accordance with the court decision. On this note, it might be added that court decisions and judgments do not create case-law in the Anglo-Saxon legal tradition. German rulings correct the violation at hand, set a precedent for similar cases, and create interpretation standards.

In view of the two principal options to seek legal remedy, a number of cases were filed in the very early phase when Germany-wide curfew ordinances were first issued. Most of them sought for temporary justice. This Vorläufiger Rechtsschutz allows claimants to have an accelerated court procedure. The court then makes a temporary decision. This may be altered by a later decision when the court finds the time to assess the case in substance. Legal review is also possible in those cases where the authority immediately executes an administrative act (i.e., dissolving a curfew-violating assembly or demonstration). ${ }^{5}$ These cases are filed with a view to an ex-post evaluation. In the case of a finding favoring a claimant's view, the court would declare the measure to have been taken illegally. One effect of those decisions is its recommending character for future executive actions. Authorities are required to rethink their intended course of action in lieu of comparable cases.

In the following section, I will present a few decisions which were decided by various court levels. They include a decision by Germany's highest court, the Federal Constitutional Court in Karlsruhe, but also by constitutional courts on statelevel, and a higher administrative court of a Land. Most of those court decisions were made under the accelerated procedures to seek temporary justice. This selection illustrates how cases are dealt with by various courts in different German regions. I have also selected cases with a variety of alleged violations of basic rights.

\section{The Federal Constitutional Court / Freedom of Assembly}

Germany's Constitutional Court decided that the City of Gießen (located near Frankfurt in the State of Hesse) had to allow a demonstration of around 30 persons at a centrally located square. ${ }^{6}$ In accordance with procedures, the demonstrators had announced the proposed assembly to the respective office of Gießen's city administration. The demonstrators also presented a scheme showing how participants could maintain the necessary distance from each other and how speeches could be broadcast. The city rejected the demonstration and referred to the first paragraph of the previously introduced Hessian ordinance that

5 Volkmar Götz, Allgemeines Polizei- und Ordnungsrecht, 10th ed. (Göttingen: Vandenhoeck \& Ruprecht, 1991), p. 151 et seq.

6 Bundesverfassungsgericht, Beschluss vom 15. April 2020, 1 BvR 828/20; see: Pressemitteilung Nr. 25/2020 vom 16. April 2020 Antrag auf Erlasss einer Einstweiligen Anordnung gegen Versammlungsverbot teilweise erfolgreich. 
mandated a temporary curfew. Immediate appeals to the city, the competent administrative court, and the Hessian Higher Administrative Court were not successful. Hence, the case was filed to the Constitutional Court since the claimants argued that the prohibition of the demonstration would violate their right to Freedom of Assembly (Basic Law, Article 8: All Germans shall have the right to assemble peacefully and unarmed without prior notification or permission). The city's legal advisors argued that the ordinance had to be understood as a law regulating outdoor assemblies. Article 8 of the Basic Law states in paragraph 2 that the right to assemble may be restricted by or pursuant to law. They interpreted the curfew decree that residents have to reduce physical and social contacts with persons other than members of their own household to an absolute minimum, which would not be possible in demonstrations. The Constitutional Court, however, emphasized that the city enjoyed discretion to decide on the demonstration according to Germany's Assembly Act (Section 15 on Prohibition, Dissolution, and Instructions, paragraph 1: The competent authority may prohibit the assembly or procession or make it dependent on specific instructions if in accordance with the circumstances recognizable at the time of issuing the injunction public security or order is directly endangered by the implementation of the assembly or procession). The judges criticized that Gießen's administration belief that the curfew could prohibit any demonstration as such and that no attempt was made to elaborate the case-related circumstances. The court found that the Hessian decree did not forbid all demonstrations.

Furthermore, Karlsruhe underlined that the freedom to assemble is an essential constitutional right that had to be taken into consideration. ${ }^{7}$ The Constitutional Court ordered the City of Gießen to re-evaluate its decision in the light of this interpretation. The city did so, and the demonstration took place. A couple of persons met in an arranged manner to keep the required physical distance between the demonstrators.

\section{The Constitutional Court of Saarland / Personal Freedom}

In a temporary legal decision from 28 April 2020 that was discussed Germanywide, the Constitutional Court of the Saarland (a fairly small German western state bordering France and Luxemburg) ruled, at the very beginning of the curfew, on the prohibition to leave one's home. ${ }^{8}$ The claimant challenged the Saarland ordinance mandating a temporary curfew. This ordinance was modeled in accordance with the Bavarian decree. The Saarland ordinance also urged residents to stay at home and to reduce contact with persons other than members of their own household. The Saarland ordinance also ruled on the occasions when a person was allowed to leave their own home. This was permitted only

See also: Dieter Hesselberger, Das Grundgesetz, 12th ed. (Bonn: Bundeszentrale fuer politische Bildung, 2001), p. 127.

8 Verfassungsgerichtshof des Saarlandes, Beschluss vom 28. April 2020, Lv 7/20. 
for good reasons. The ordinance burdened the individual with the need to provide a valid explanation as to why he or she had left home.

The claimant, in this case, stated that the respective sections limited his personal freedom and that he had a right to be in a public space without a duty to give any specific reasons. In its decision, the Saarbrücken-based Constitutional Court first elaborated on the claimant's rights to seek temporary justice at the highest court of the Saarland. It basically approved the procedure by arguing that the legal question at stake is of "general interest" and that the decree had the potential to violate many basic rights of innumerable residents. When making its legal assessment, the court conceded that the executive branch had the responsibility to evaluate the threat to the life and health of its citizens posed by the pandemic. Hence, the court, generally, understood that the right to freedom might be limited under these circumstances. It then equally stressed that the impact of the right to freedom, a right of utmost importance to liberal democracy, requires a constant control by the judiciary. Henceforth, the judges argued that the governmental justifications backing curfew regulations would have to be continuously reviewed. This is where the court touched upon the very debate of data generated by virologists suggesting harsh de-socializing measures to prevent the further spread of COVID-19. The court compared the number of infections with other German states bordering European countries. The judges linked those higher infection rates with the figures of infection rates in the home state. The Constitutional Court then denied that the data would be of significance for the stand taken by the Saarland Government. It even went so far as to cite a study by the ETH Zurich (Swiss Federal Institute of Technology in Zurich) entitled "The estimated impact of non-pharmaceutical interventions on documented cases of COVID-19: A cross-country analysis." ${ }^{9}$ According to this study, curfew restrictions have "only a small added value," and one also had to consider that "lockdowns also entail a ban on public events and gatherings." The judges followed this line of argument when balancing the government's intention to maintain public health and minimize deaths against the individual's right to freedom. The court continued by applying the figures to the case of those who suggest tighter restrictions and to that of those favoring an easing of the curfew. Applying the Saarland decree to different scenarios of social gatherings, the court wondered, in an excessive tone, why family members could be allowed to attend the burial of a deceased relative under the curfew ordinance, whereas people were prohibited from gathering in social settings. The court emphasized that it did not intend to act as legislator, but it recommended that the government should reformulate the respective sections in the curfew decree. The recommendations stipulated that the burden should be shifted from the resident to explain

9 Nicolas Banholzera, Eva van Weenen, Bernhard Kratzwald, Arne Seeliger, Daniel Tschernutter, Pierluigi Bottrighi, Alberto Cenedese, Joan Puig Salles, Werner Vach, and Stefan Feuerriegel, "Impact of Non-pharmaceutical Interventions on Documented Cases of COVID-19: A Cross-country Analysis," medRxiv, April 21, 2020, https://doi.org/10.1101/2020.04.16.20062141. 
why he or she leaves home. In light of this decision, everybody can now leave their home whenever they please. It is up to the government to justify any future constraints on the basis of convincing evidence.

\section{Higher Administrative Court Munich / Non-Discrimination}

Another, intensively debated, decision by an administrative court took place in Bavaria. ${ }^{10}$ At the beginning of May 2020, the Munich-based government started to ease the constraints and amended its respective ordinances to allow shops with a maximum floor space of $800 \mathrm{~m}^{2}$ to re-open. The claimant-a corporation of popular shopping centers in Munich, Berlin and Hamburg-argued that the principle of non-discrimination according to Article 118 of the Bavarian Constitution (Everyone shall be equal before the law. The laws shall bind everyone in the same manner and everyone shall enjoy the protection of the laws in the same manner) had been violated. The shopping center consortium sought for temporary legal protection after the amended decree was announced. The procedure went straight to the Bavarian Higher Administrative Court. When assessing whether the restriction to allow retail businesses with a maximum floor space of up to $800 \mathrm{~m}^{2}$ to re-open violated the principle of non-discrimination, the court generally stated that legislators are allowed to treat different cases in a different manner. However, the court added, in case the government does wish to apply such different standards to different scenarios, it must thoroughly substantiate its reasoning. The Munich-based Higher Administrative Court did not see any discrimination in the different assessments of the risk of infection in a suburban tool store or a city center shopping mall. But it did consider the easing of restrictions in favor of larger book or bike stores as discriminatory when related to the constraint of keeping shopping malls de facto closed due to the $800 \mathrm{~m}^{2}$ rule. The court also found that the new curfew decree violated the principle of proportionality. It underlined the severe impact of the restriction on the owners' rights and could not share the government's view why, in particular, the space of $800 \mathrm{~m}^{2}$ was determined to set the threshold. In consequence, Bavaria's government had to allow the shopping centers to open.

\section{Constitutional Court of Berlin / Free Development of Personality}

Berlin is not only Germany's capital, it is also a Land. It is similar to two other Länder with little territory - the Hanseatic Cities of Hamburg and Bremen. These three form, with the 13 Flächenstaaten, the 16 states of the Federal Republic. Thus, the city of Berlin has a Constitutional Court. A member of Berlin's bar filed a case to the Constitutional Court, where he asked for temporary legal protec-

10 "Corona-Pandemie - Keine Aussetzung des Vollzugs der Bayerischen Infektionsschutzmaßnahmeverordnung," Beschluss vom 27.04.2020 - 20 NE 20.793 (Verwaltungsgerichtshof München, 2020), https://www.gesetze-bayern.de/Content/Pdf/Y-300-ZBECKRS-B-2020-N-6630?all=False. 
tion. ${ }^{11} \mathrm{He}$ claimed that the Senate's curfew restrictions (Berlin's executive power is equal to that of the governments in Germany's territorial states) and the corresponding register of fines per se were breaches of his constitutional rights and freedoms. He argued that the curfew would prevent him from participating in professional assemblies, visiting libraries, and departing from his home. In sum, he saw the freedom of development of his personality was being endangered (Freie Persönlichkeitsentfaltung ${ }^{12}$ ). The court dismissed the case. The majority of judges considered that the Senate's interest in maintaining a functioning health system and its efforts to flatten the curve of COVID-19 infected citizens was of the utmost importance. They pictured a situation in which individuals could act without any rules enforcing physical distance. The court held against the lawyer, stating that he could not substantiate why he would be considerably impacted by the Senate's decree. What makes this decision also noteworthy is the fact that two constitutional judges published dissenting opinions - which is unusual in the German legal tradition. They specifically criticized the decree and the list of fines with regard to their clarity, its preciseness (Bestimmtheit ${ }^{13}$ ), and their lack of a thorough explanation as to why the specific restrictions justified those severe impacts on basic rights.

\section{Summary}

The cases mentioned above were only a selection. New decisions and, sometimes, judgments are being taken on a daily basis. It would be easily possible to continue with many other cases that would illustrate how administrative and constitutional courts have tried to balance basic rights and public health needs. One could ask whether it is possible to observe any particular features from German administrative jurisdiction. It clearly is.

Just by focusing on the results, one can see that the claimant does not always prevail. For instance, the Leipzig Administrative Court decided against a father who wished to attend the birth of his children. ${ }^{14}$ The judges decided that the hospital's interest in maintaining a virus-free health institution was higher than the father's desire to witness the delivery of his twins. Sometimes the courts

11 Verfassungsgerichtshof des Landes Berlin, "VerfGH Berlin: Erfolgloser Eilantrag eines Rechtsanwaltes im Zusammenhang mit der Covid19-Pandemie - Folgenabwägung Sondervotum," April 14, 2020, 50 A 20/20, www.gerichtsentscheidungen.berlinbrandenburg.de/jportal/?quelle=jlink\&docid=KVRE001092015\&psml=sammlung.psm I\&max $=$ true \&bs $=10$.

12 See Peter Schade, Grundgesetz mit Kommentierung (Regensburg: Walhalla Fachverlag, 2001), p. 23 et seq.

13 Steffen Detterbeck, Allgemeiens Verwaltungsrecht (München: C.H.Beck, 2002), p. 64.

14 "VG Leipzig gibt einem Krankenhaus Recht: Kreißsaalverbot für werdende Väter rechtens," Legal Tribune Online, May 6, 2020, on Verwaltungsgericht Leipzig, Beschluss vom 09.04.2020, Az 7 L 192/20, https://www.Ito.de/recht/nachrichten/n/vgleipzig-7|19220-kreisssaal-verbot-vater-geburt-corona-hausrecht-krankenhaus-klinik. 
agreed with the broad set of restricting instruments but doubted a specific subset.

One feature is that German jurisdiction stands by its tradition to concentrate on the very individual case and the assessment of the specifics (Einzelfallbetrachtung)..$^{15}$ In consequence, individuals (or legal entities) will continue to file their cases. Unfavorable decisions or judgments do not necessarily mean that a court would not assess a detailed facet differently in a different procedure.

The judges recognized the usefulness of introducing physical-distancing restrictions or obligations to wear protective gear, but they also acknowledged the economic or societal consequences of a lockdown. Overall, the courts did not seek to enter into the heated public debate on the trilemma of protecting the public health system, upholding civic rights, and maintaining a functioning economy. When studying the decisions carefully, one can conclude that the judges repeatedly required the governments to justify their constraints adequately. So far, the emphasis has been on a particular chosen legal tool, which was challenged. The judges deciding in favor of a claimant have lamented that proper data had not been put in proportion to the application of a specific measure that limited individual rights and freedoms. This led to the key observation that federal and state courts should strictly adhere to the principle of proportionality. ${ }^{16}$ A restricting measure can only be legal if the public aim is clear, if it is necessary, if no milder measure is at hand, and if maintaining the public aim is so pre-eminent that it justifies the intensity of a limitation of a basic right.

When putting the coronavirus-related administrative court decisions into the German political context of late spring/early summer 2020, one must acknowledge that the judges served their function well in providing checks and balances. After several weeks of lockdown (which was relatively modest compared to some western and southern EU member states), the discussion on pro and counter restrictions became much more political and emotionalized than in early spring. The tone changed, even within political camps. Some politicians could not even hide their public dismay in lieu of some court decisions (which is usually anathema in German politics). In the meantime, Berlin, Stuttgart, Munich, and other cities witnessed demonstrations by thousands of citizens who ignored the decreed physical distancing rules rallying for a "back to normal" situation.

Germany's criminal courts have so far escaped dealing with corona-related legal questions. During the critical phase of March and April 2020, the state-run health systems have managed to keep the number of patients requiring respiration low until they could upgrade their intensive care equipment. Hence, no case was filed to a criminal court for judgment on what became known as triage. So, no physician has yet been accused of a decision on prioritizing a patients' treatment based on the likelihood of recovery with or without treatment. The assess-

15 Detterbeck, Allgemeiens Verwaltungsrecht, pp. 131, 132.

16 Münchow, "COVID-19: How to Implement a Lockdown," pp. 14-16. 
ment of these scenarios under the criminal code and constitutional requirements deserves another article.

\section{Outlook}

The administrative court decisions so far can be seen to be sober interventions that did not question the aim to prevent a further spread of the virus but were made in order to tame any overambitious measures by governments to maintain public health at the cost of individual freedoms and rights. One might even add that the court rulings paid respect to the very nature of the pandemic. Infections rose in Germany's industrial hubs cross-linked with globalization. COVID-19 broke out in and around nursing homes. It spread in skiing resorts. Yet, it occurred in lower numbers along the less populated Baltic shores. Hence, the local circumstances were taken up by courts asking for proportional and regionaldriven measures. The location of a business, the proximity to a border with a country of higher infection rates matter, and so do detailed precautions about the organization of a demonstration. The rulings considered not only the specific circumstances but also the individual in an in dubio pro libertate spirit.

Looking at it from the macro-level perspective mentioned at the beginning of this article, Germany's government never had the tools to seal off an urban area of 10 million inhabitants. Nor does the 1949 Basic Law allow Germany's administration to force citizens to download tracking apps. Needless to say, critical researchers, doctors, bloggers, and journalists did not "disappear" or fall mysteriously from windows. ${ }^{17}$ Related to the pandemic, the Federal Government refrained from any strong rhetoric in an attempt to bully external challengers. It withstood attempts to sell humanitarian relief operations to a global audience by fishing for respect and compliments. Unlike Russian or Chinese activities, where arriving medical equipment was accompanied by platoons of regimefriendly journalists to create positive images and narratives, the hospital treatments of Italian and French patients went largely unheralded. The Berlin administration did not react to Moscow's coquettish offers at the height of the crisis. Instead, Saxony considered offering beds to Russian patients so that they could be cured of COVID-19 in German hospitals. The German crisis-management appears to have been clearheaded. Its health system survived the outbreak in the spring of 2020 remarkably well and currently, Germany's diplomats negotiate the financial protective shields on behalf of its European partners. In parallel, its Ministry of Defense tries to explore new ways to promote EU-NATO cooperation to ensure future military mobility, ways of countering joint hybrid threats, and similar problems. The calm way that courts balanced the instruments to fight the

17 "Corona-Zensur in China: Die verschwundenen Blogger von Wuhan," Tagesschau.de, May 23, 2020, https://www.tagesschau.de/ausland/china-blogger-101.html; see also: "Mysteriöse Todesumstände: Zwei russische Ärzte nach Systemkritik durch Fenstersturz gestorben," t-online.de, May 5, 2020, https://www.t-online.de/nachrichten/ ausland/id_87819616/corona-in-russland-zwei-aerzte-nach-kritik-durch-

fenstersturz-gestorben.html. 
coronavirus with Rule-of-Law concerns contributed to the necessary mosaic of the overall achievements. In sum, one might also keep in mind this thorough Rule-of-Law based way, the freedom to access legal remedies and a sound judiciary when countering the narratives of authoritarian regimes in the East that are claiming to serve societies better in the combat against COVID-19.

\section{Disclaimer}

The views expressed are solely those of the author and do not represent official views of the PfP Consortium of Defense Academies and Security Studies Institutes, participating organizations, or the Consortium's editors.

\section{Acknowledgment}

Connections: The Quarterly Journal, Vol. 19, 2020 is supported by the United States government.

\section{About the Author}

Dr. Sebastian von Münchow is a member of the faculty at the George C. Marshall European Center for Security Studies in Garmisch-Partenkirchen, Bavaria. He studied law at the Free University of Berlin, the Université de Lausanne, and the Christian-Albrechts-University Kiel. In 2000, he earned his doctorate in International Relations at the University of Vienna. From 1998 to 2002, he worked for the field missions of the Organization for Security and Co-operation in Europe in Bosnia and Herzegovina, as well as in Kosovo. He has also served in the Police Assistance Mission of the European Union in Tirana. Between 2003 and 2005, Dr. von Münchow led various home and justice-related initiatives in the Brusselsbased Office of the Special Coordinator of the Stability Pact for South-Eastern Europe. In 2006, Dr. von Münchow returned to Germany and worked for several years in the Federal Chancellery in Berlin before joining the Marshall Center in 2012. His areas of expertise include parliamentary oversight, rule of law and capacity building in South-Eastern Europe. Since 2019, Dr. Sebastian von Münchow is the Director of the European Security Seminar East. 